\title{
Octave Mirbeau, La morte di Balzac
}

\section{Ida Merello}

\section{(2) OpenEdition}

\section{Journals}

\section{Édition électronique}

URL : http://journals.openedition.org/studifrancesi/565

DOI : 10.4000/studifrancesi.565

ISSN : 2427-5856

\section{Éditeur}

Rosenberg \& Sellier

\section{Édition imprimée}

Date de publication : 1 avril 2015

Pagination : 183

ISSN : 0039-2944

\section{Référence électronique}

Ida Merello, «Octave Mirbeau, La morte di Balzac », Studi Francesi [En ligne], 175 (LIX | I) | 2015, mis en ligne le 01 avril 2015, consulté le 18 septembre 2020. URL : http://journals.openedition.org/ studifrancesi/565; DOI : https://doi.org/10.4000/studifrancesi.565

\section{Ce document a été généré automatiquement le 18 septembre 2020}

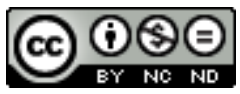

Studi Francesi è distribuita con Licenza Creative Commons Attribuzione - Non commerciale - Non opere derivate 4.0 Internazionale. 


\title{
Octave Mirbeau, La morte di Balzac
}

\author{
Ida Merello
}

\section{RÉFÉRENCE}

octAVe mirbeAu, La morte di Balzac, a cura di Davide VAGo, Milano, Sedizioni, 2014, pp.

140.

octAVE mirBeAu, La morte di Balzac, a cura di Eileen romano, Milano, Skira 2014, pp. 66.

1 Escono pressoché contemporaneamente due traduzioni (due prime traduzioni, dunque) del racconto sulla morte di Balzac, che Mirbeau, cedendo alla volontà della figlia di Mme Hanska, tolse dall'opera La 628-E 8 (1907), quando era già stata stampata da Fasquelle. Si trattava infatti di una storia fortemente lesiva dell'immagine della contessa, che avrebbe ricevuto il suo amante, il pittore Jean Gigoux, durante l'agonia di Balzac, secondo quanto lo stesso Gigoux avrebbe molto più tardi rivelato a Mirbeau.

D. VAGO, nella postfazione, rintraccia legami sotterranei con altri episodi del romanzo, arrivando quindi alla conclusione che non valga la pena domandarsi se il racconto sia vero o falso, quanto ritrovarvi i temi dominanti di Mirbeau, l'ossessione della carne, la meschinità e la miseria umane.

3 E. ROMANo, invece, si limita a riportare la storia dell'edizione, sospendendo il giudizio sulla verità storica.

4 Non è qui la sede per un'analisi delle traduzioni, che peraltro mostrano subito un timbro molto diverso: scrittura più ricercata, con termini meno usuali, quella di Vago, limpida e lineare quella di E. Romano. Vago fa seguire al testo italiano quello francese (compresa la postfazione, in due lingue). 